\title{
高層集合住宅における居住意識と生活行動に関する調査研究 FIELD SURVEY ON THE CONSCIOUSNESS OF LIVING ENVIRONMENT AND THE LIFE-STYLE OF OCCUPANTS LIVED IN HIGH-RISE APARTMENT BUILDINGS
}

\author{
赤林伸一*, 足立直之**, 高倉秀一***, 長谷川 功****, 坂口淳** \\ Shin-ichi AKABAYASHI, Naoyuki ADACHI, Shuichi TAKAKURA, \\ Kou HASEGAWA and Jun SAKAGUCHI
}

The field survey is conducted to clarify the actual problems of high-rise living. Me analyzed following aspects. (1) Most people attatch the importance to the price of house and the living environments, when they decide where to live. (2) The people who lived in the detached house before, have the tendancy to live highrise sections of the appartment building. (3) About the children's playing place,there are no clear effects of the height of present living floor. (4) The effects of houserive's frequency of out-goings, are not only the height of living floor but housewives' work, age, and the existence of low-age children.

KEYTORDS: HIGH-RISE APARTNENT BUILDINGS,LIFE-STYLE, CONSCIOUSNESS OF LIVING ENVIRONMENT, OLD AGE, INFANTS

高層集合住宅，住まい方，居住意識，高路者。幼児

\section{1. 調查目的}

昭和 38年の建築基準法の一部改正により、31 mの高 さ制限がなくなり、昭和 43 年の霞が関ビルの完成を期 に、日本における超高層時代が始まる。一方、超高層 住宅は、昭和 44 年に完成した三井綱町パークマンショ ン $(19 \mathrm{~F})$ 以降続々と建設されており、1993年7月現在で は、その棟数は 200 余りに達している。

超高層ビル建設は、超高層建築技術の発達を背景に、 オフィス面積の不足、地洒の高騰をその要因として、 主に首都圈を中心にその高さと数を增している。さら に、超高層住宅の持つ眺望の良さ、管理面での優位さ、 防犯性等への期待が居住者側に存在し、需要の側面か らも超高層建築建設を推進してきたと考えられる。 また、いわゆるバブルがはじけた現在でも、都市部近 郊の 3000 万〜 5000 万円程度のマンション市場は平成 5 年 9 月の月間契約率が $83.3 \%$ とった好況を呈してい る（注 1 ）。一方、都市人口の減少をくいとめ都市の
再生を目的とする社会資本としての都市居住空間の創 造に関する研究（注 2 ）や、都市におりる立体的用途 規定の研究 (注 3) 西盛んに行われており、今後の日 本における都市居住では、住宅の高密度化・高層化は 依然として避けられないものと考えられる。この様な 状況を鑑み、本研究では、高層と超高層の混在する住 宅団地を対象とした居住者属性・生活実態・居住意識 に関するアンケート調查を行い、高層集合住宅居住に おける種々の問題点を、建築計画や設備計画の立場か ら抽出し整理するとともに、高層集合住宅設計のため の基礎資料の蓄積を行うことを目的とする。

\section{2. 既往の研究・文献調査}

高層集合住宅居住に関する現状と問題点を把握する ため、1991年以前に公表された集合住宅に関する既往 の研究の目的と要旨を整理する。表 1 に調査結果を示 す。母子・幼児の問題に関する田中ら $(1990$, №.5)の研

\footnotetext{
* 新潟大学工学部建設学科 助教授. 工博

** 新潟大学工学部建設学科 大学院生

***(株) 間組 技術研究所 主席研究員

**** (株) 三井建設 技術研究所 主任研究員

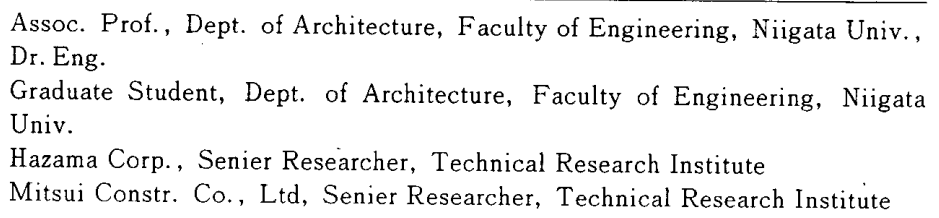

Assoc. Prof., Dept. of Architecture, Faculty of Engineering, Niigata Univ., Dr. Eng.

Graduate Student, Dept. of Architecture, Faculty of Engineering, Niigata Univ.

Hazama Corp., Senier Researcher, Technical Research Institute Mitsui Constr. Co., Ltd, Senier Researcher, Technical Research Institute 
究では、幼児は高層住宅特有の空間特性の影響を強く 受け、外出の自立が遅れ母親の付き添い負担が增える と指摘している。織田ら(19.91, №.1〜3)の研究でも、高 層居住は、母子の行動パターンに影響を及ぼす可能性 があり、母子の外出不足や過度な密着、子供同士のつ きあいの減少等の問題点を明らかにしており、これら の問題点の解決には、建筑・居住者の両面からの対策 が必要と指摘している。小柳津ら(1990, No.8)は、超高 層居住時の問題点を把握し、共用施設、 $E \mathrm{~V}$ 、階段、 防犯設備や管理上の問題を建築計画上の検討課題にす べきとの問題提起を行っている。高齢者に関する研究 では、大井ら(1991，№.11)が、高秢者の主観的ＱＯL は 高齢になるほど一年を通じての生活の張りや満足度、 幸福感の変動が少なく、逆に I A D L（注 5 ）は、80 歳を過ぎると 1 年を経て著しく低下すると報告してい
る。また、谷口ら (1989, №.12)の研究では、高齢者の超 高層住宅に対する永住意識等について報告している。 しかし、高龄者の高層居住における設備面での問題に ついて提起した研究例は見られない。また、東樋口ら (1989, №.16)の芦屋浜集合住宅に関する一連の研究では、 居住者のライフステージの変化に空中庭園やオープン スペースといった建物機能が対応しなくなったと指摘 している。これらの研究成果では、高層居住に係る問 題は我々を取りまく社会環境、幼児や高歯者、居住者 の意識、設備、防犯、経年変化といった複数の要因に 起因しており一元的に解決できる問題ではないことが 指摘されている。本研究では、これらの既往の研究と の対比を通して高層集合住宅設計の基礎資料とする。

表 1 高層集合住宅に関する既往の研究一覧

\begin{tabular}{|c|c|c|c|c|c|}
\hline 分類 & NO & 文献タイトル & 研 究 目 的 & 旨 & 出 典 \\
\hline \multirow{6}{*}{ 幼子 } & 1 & 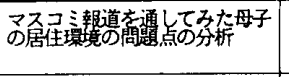 & 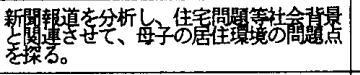 & 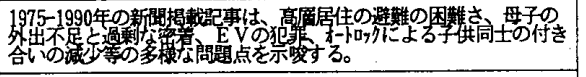 & \multirow{3}{*}{ 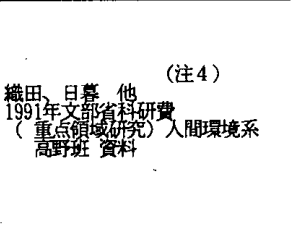 } \\
\hline & 2 & 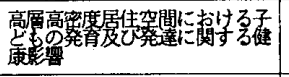 & 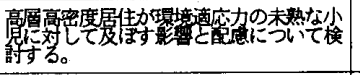 & 豪屏柿る。 & \\
\hline & 3 & 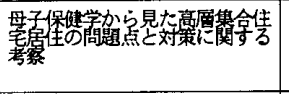 & 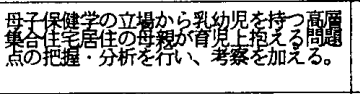 & 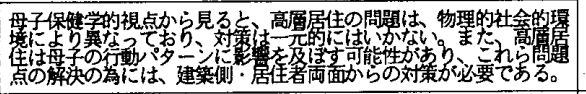 & \\
\hline & 4 & 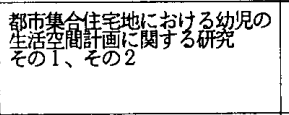 & 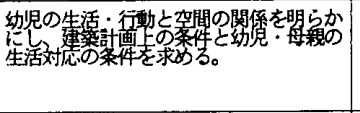 & 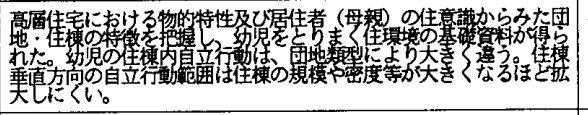 & 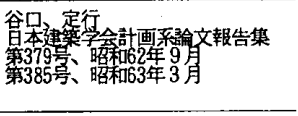 \\
\hline & 5 & 隹合集完環境亡幼䝨の外出行動 & 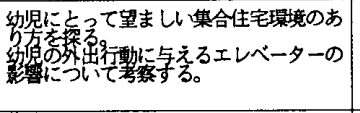 & 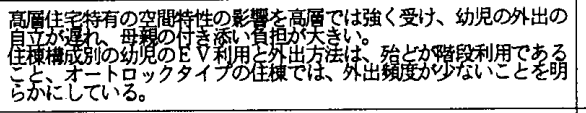 & 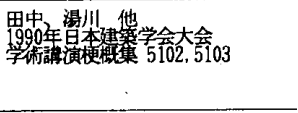 \\
\hline & 6 & 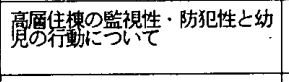 & 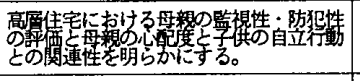 & 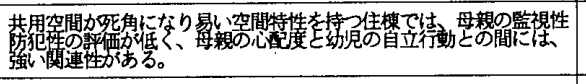 & 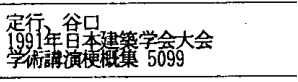 \\
\hline \multirow{4}{*}{$\begin{array}{l}\text { 高不 } \\
\text { 住宅 } \\
\text { 計画 }\end{array}$} & 7 & 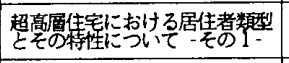 & 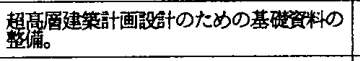 & 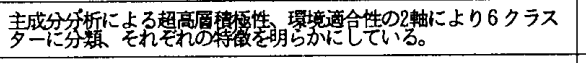 & 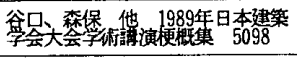 \\
\hline & 8 & 超毃層住宅計画の諸問題 & 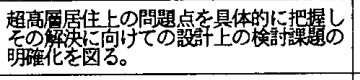 & 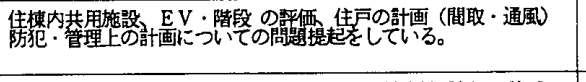 & 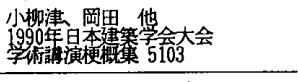 \\
\hline & 9 & 膏層集合住宅計画の動向に関す & 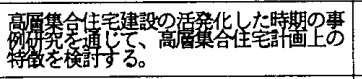 & 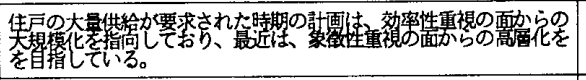 & 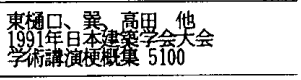 \\
\hline & 10 & 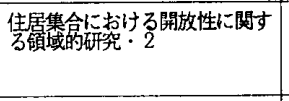 & 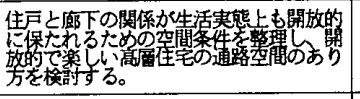 & 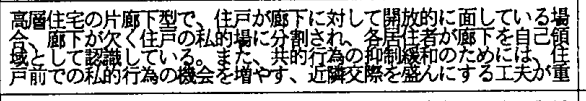 & 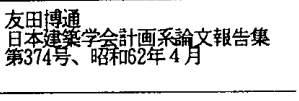 \\
\hline \multirow{2}{*}{ 高 } & 11 & 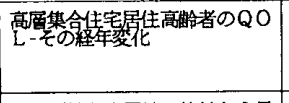 & 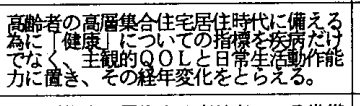 & 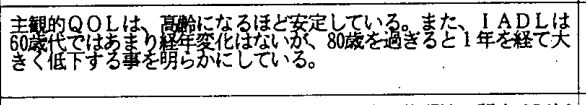 & 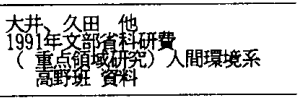 \\
\hline & 12 & 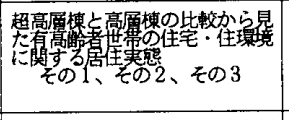 & 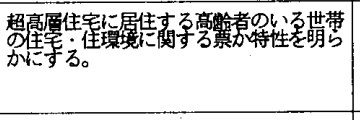 & 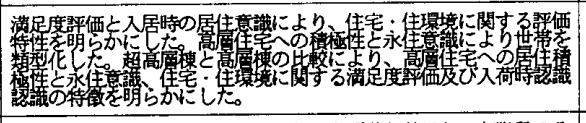 & 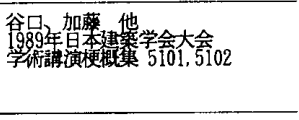 \\
\hline 外 & 13 & 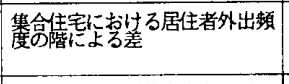 & 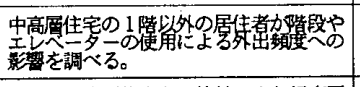 & 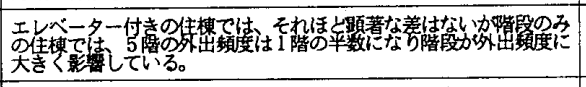 & 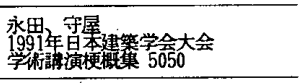 \\
\hline \multirow{2}{*}{$\begin{array}{l} \\
1 \\
7 \\
x \\
y \\
1 \\
u\end{array}$} & 14 & $\begin{array}{l}\text { 超高層住息の居售者像とライフ } \\
\text { その1、その2、その3 }\end{array}$ & 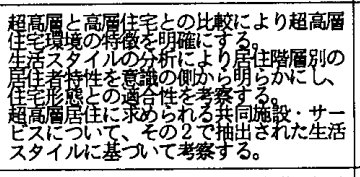 & 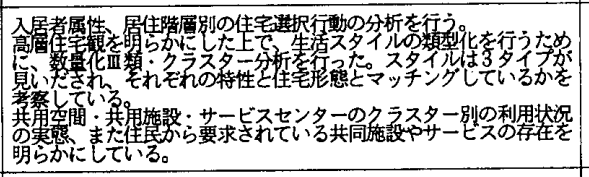 & 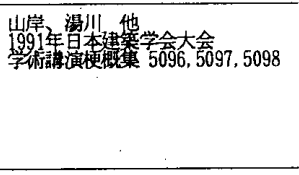 \\
\hline & 15 & 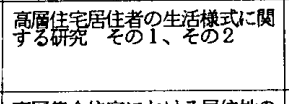 & 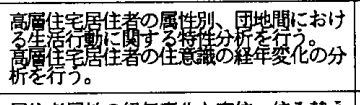 & 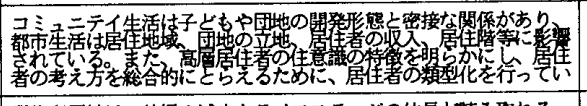 & 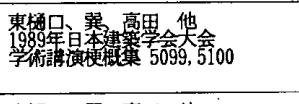 \\
\hline 变化 & 16 & 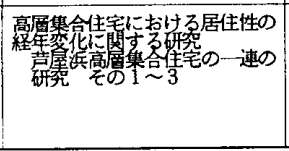 & 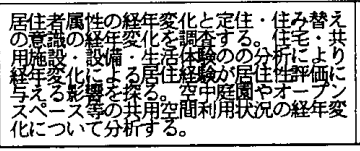 & 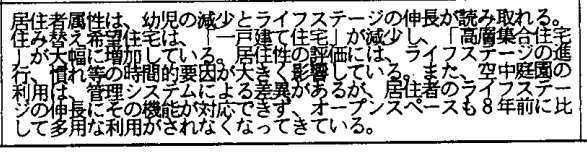 & 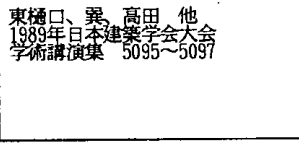 \\
\hline
\end{tabular}




\section{3. 調査の概要}

\section{1 調查対象}

調查対象は、高層・超高層集合住宅の混在する団地 として計画された $\mathrm{P}$ 団地（神奈川県川崎市）の集合住 宅 9 棟を対象とする。住棟の配置図を図 1 に、対象住 宅の属性を表 2 に示す。

\section{2 調查方法}

平成 3 年 11 月に $\mathrm{A} \sim \mathrm{J}$ 棟（ $\mathrm{H}$ 棟は体育館のため除く） の全住戸(1645戸)の郵便受けにアンケート調査表を配 布し、各住棟に設置した回収ボックスに投函してもら う。回収数は 909 であり、回収率は $55 \%$ である。表 3 に各棟の回収率を示す。

\section{3 調查内容}

表 4 に調查内容の概要を示す。調查内容は、(1)住戸 の属性を把握するための、居住階、家族構成、年秢構 成、住戸の広さ等に関する設問、(2)高層集合住宅に対 する意識を把握するための現在の住まいの購入理由ゃ 居住階、現在と以前の住まいとの比較に関する設問、 (3)超高層集合住宅の住まい方を把握するための主婦の 外出頻度や子供の遊び場等に関する設問、(4)防犯体制 やエレベーター等の設備に対する意識に関する設問、 (5)入居者の住戸に対する趣向に関する設問等である。

\section{4 単純集計結果}

4. 1 居住階と年湛構成・家族人数

回答者の居住階層を図 2 に示す。1 4 階の中低層 居住が $26 \% 、 5 \sim 14$ 階の高層居住が $60 \% 、 15$ 階以上の 超高層居住は13\%である（注6）。居住者の年跲構成 を図 3 に示す。 5 葴以下の幼児がいる住戸は $38 \%$ あ り、65歳以上の高齢者がいる住戸は約 $8 \%$ ある。居 住階層別の家族人数を図 4 に示す。どの階層とも 4 人 家族が最す多い。一人暮らしの割合は、中低層階では $4 \%$ あるるが超高層階になると $9 \%$ と增加する。逆に

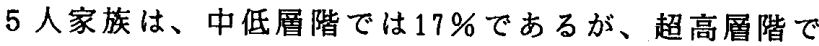
は $4 \%$ に減少する。

\section{2 転居前の住居}

図 5 に現在の住宅に転居する以前の住戸を現在の居 住階層別に示す。中低層階と高層階では集合住宅から 転居した割合が高く、それぞれ78\%、79\%である。逆 に超高層階では、一戸建て住宅から転居した割合が 47 \%と增加している。

\section{3 住宅の選択理由}

図 6 に現在の集合住宅を購入した理由を示す。「こ の住宅を望んだ訳ではなく、環境や価格、通勤・通学 時間などが適切であるから」という理由が $64.1 \%$ と最 あ多く、「集合住宅のほうが一戸建て住宅に比較して 住居環境（周辺の環境、管理、安全性等）として優れ ていると思ったから」と回答した住戸の割合は $22.8 \%$

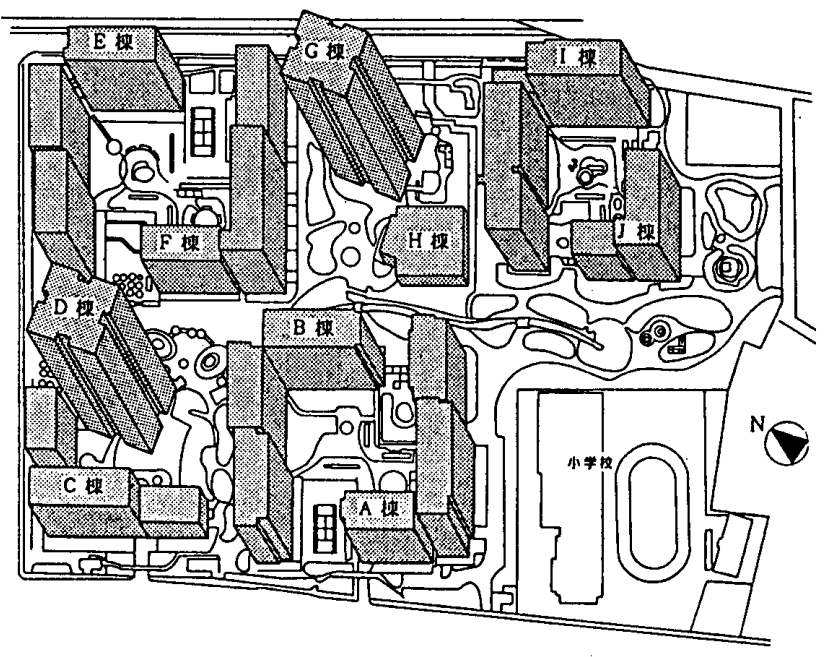

図 1 調查対象集合住宅の配置図

表 2 調查対象巢合住宅の属性

\begin{tabular}{|c|c|c|c|c|c|c|c|c|c|c|}
\hline \multirow{2}{*}{\multicolumn{2}{|c|}{ 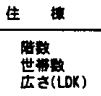 }} & A & B & c & D & $E$ & $F$ & 0 & 1 & $J$ \\
\hline & & $\begin{array}{r}13 \text { 陪 } \\
19997 \\
2 \sim 4\end{array}$ & 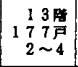 & $\begin{array}{ll}1 & 0 \\
6 & 4 \\
2 & \sim 4 \\
2 & \sim 4\end{array}$ & $\begin{array}{r}30 \\
21 \\
2 \\
2 \\
2 \sim 4\end{array}$ & $\begin{array}{r}15898 \\
2628 \\
2 \sim 4 \\
\end{array}$ & $\begin{array}{r}13 \\
1947 \\
2 \sim 4 \\
2 \sim 4\end{array}$ & $\begin{array}{r}30 \% \\
218 \\
2 \sim 4 \\
2 \sim 4\end{array}$ & $\begin{array}{r}15 \text { 屡 } \\
2224 \text { 年 } \\
2 \sim 4\end{array}$ & $\begin{array}{l}1117 \\
957 \\
2 \sim 4\end{array}$ \\
\hline \multicolumn{2}{|c|}{ 住相形式 } & 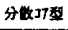 & 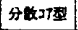 & 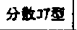 & * * & 㟗《行型 & 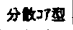 & | & 分楮J7竞 & S4) \\
\hline \multicolumn{2}{|c|}{ 所有形业 } & \multicolumn{9}{|c|}{ 分競住宅 } \\
\hline \multicolumn{2}{|c|}{ 分四年高 } & S. 59,9 & S. 59,9 & \multicolumn{2}{|c|}{ S. 62,11} & S. 61.5 & S. 61.4 & S. 61.10 & S. 60.5 & S. 60.6 \\
\hline \multicolumn{2}{|c|}{ 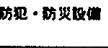 } & \multicolumn{9}{|c|}{ 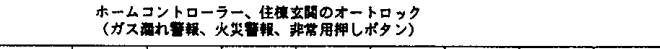 } \\
\hline E & 18 & 108 & 9. & 5: & $3 \mathrm{E}$ & 9 : & $10 \%$ & 3 & 9. & 5 政 \\
\hline v & 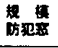 & \multicolumn{9}{|c|}{$\begin{array}{c}9 \text { 人卌り } \\
\text { 有り }\end{array}$} \\
\hline \multirow{2}{*}{\multicolumn{2}{|c|}{ 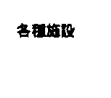 }} & \multicolumn{2}{|c|}{ 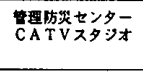 } & & 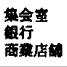 & 敏行 & \multicolumn{3}{|c|}{ 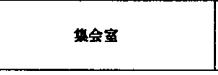 } & 四贯的 \\
\hline & & \multicolumn{9}{|c|}{ 共用トイレ } \\
\hline
\end{tabular}

表 3 アンケート回収率

\begin{tabular}{|c|c|c|c|c|c|}
\hline 棟 & A & B & C & D & $E$ \\
\hline $\begin{array}{l}\text { 世带数 } \\
\text { 回収数 } \\
\text { 回収事(\%) }\end{array}$ & $\begin{array}{rll}1 & 9 & 9 \\
1 & 2 & 8 \\
6 & 4 \%\end{array}$ & $\begin{array}{c}177 \text { 戸 } \\
94 \\
53 \%\end{array}$ & $\begin{array}{l}64 \text { 戸 } \\
36 \\
56 \%\end{array}$ & $\begin{array}{c}212 戸 \\
89 \\
42 \%\end{array}$ & $\begin{array}{rrr}2 & 6 & 2 \\
1 & 4 & 3 \\
5 & 5 \%\end{array}$ \\
\hline
\end{tabular}

\begin{tabular}{|c|c|c|c|c|c|}
\hline 拣 & $F$ & G & 1 & $\mathrm{~J}$ & 合 影 \\
\hline $\begin{array}{l}\text { 世带数 } \\
\text { 回収数 } \\
\text { 回収率 }(\text { ( ) }\end{array}$ & $\begin{array}{lll}1 & 9 & 4 \\
1 & 1 & 7 \\
& 6 & 0 \%\end{array}$ & $\begin{array}{lll}2 & 1 & 8 \bar{F} \\
1 & 2 & 4 \\
5 & 7 \%\end{array}$ & $\begin{array}{lll}2 & 2 & 4 \\
1 & 25 \\
& 5 & 6 \%\end{array}$ & $\begin{array}{l}95 \text { 戸 } \\
53 \\
56 \%\end{array}$ & $\begin{array}{r}1645 \overline{1} \\
9099 \\
559\end{array}$ \\
\hline
\end{tabular}

表 4 アンケート調查の内容

\begin{tabular}{|c|c|c|}
\hline & 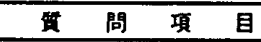 & 内 \\
\hline 1 & 現在の住まいの概要 & 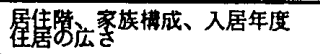 \\
\hline 2 & 現在の住まいの眐入理由 & 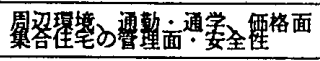 \\
\hline 3 & 以前の住まいとの比教 & 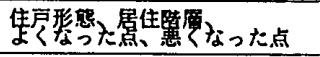 \\
\hline 4 & 主藋に閉するの䐝問 & 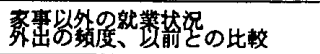 \\
\hline 5 & 子供（小学生）の遊び㺃 & 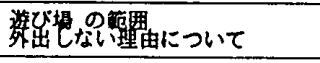 \\
\hline 6 & 防 犯 体 制 & 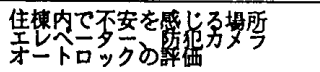 \\
\hline 7 & 冷 房 . 換 気 & 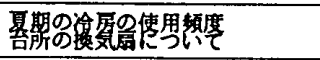 \\
\hline 8 & 転居した場合の希留 & 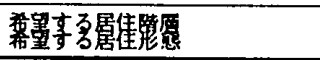 \\
\hline & 20 & $100 \%$ \\
\hline
\end{tabular}

图 2 現在の居住階 
である。住まいを購入する際に最も重視するのは、価 格・環境・通勤・通学といった要素といえる。「現在 のお住まいと同じ立地条件の一戸建て住宅（床面積は 現在と同様で庭の面積はバルコニーの面積の 2 倍程度) が同じ価格で販売されていたら集合住宅と一戸建て住 宅のどちらを選択しますか」（注 7 ）という設問に対 する結果を図 7 に示す。一戸建て住宅を選択する住戸 の割合は $18 \%$ 、集合住宅を選択する住戸の割合が $59 \%$

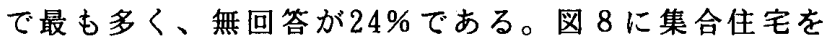
選択する理由を示す。「集合住宅の安全性」（№.1）「 管理の良さ」(№.2)がそれぞれ $23 \% 、 21 \%$ と最も多い。 「狭い一戸建てなら集合住宅のほうが良い」(№.7)は、 $11 \%$ であり、「集合住宅の利便さ」(№.9)が10\%であ る。図 9 に一戸建て住宅を選択する理由を示す。「 庭、土、木といった自然との接触」(№.1)が $26 \%$ と最 屯多い。また、「集合住宅での上下階の騷音や自分が 発生する音に対する気遺いから解放される」(№.9)む $15 \%$ と多く、次いで、「一戸建て住宅の持つ独立性」

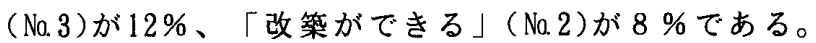

\section{4 居住階層に対する希望}

「もし、集合住宅に引っ越しするとすれば何階に引 っ越したいと思いますか」という設問に対する結果を 図10に示す。現在居住している階と同じ階を希望する
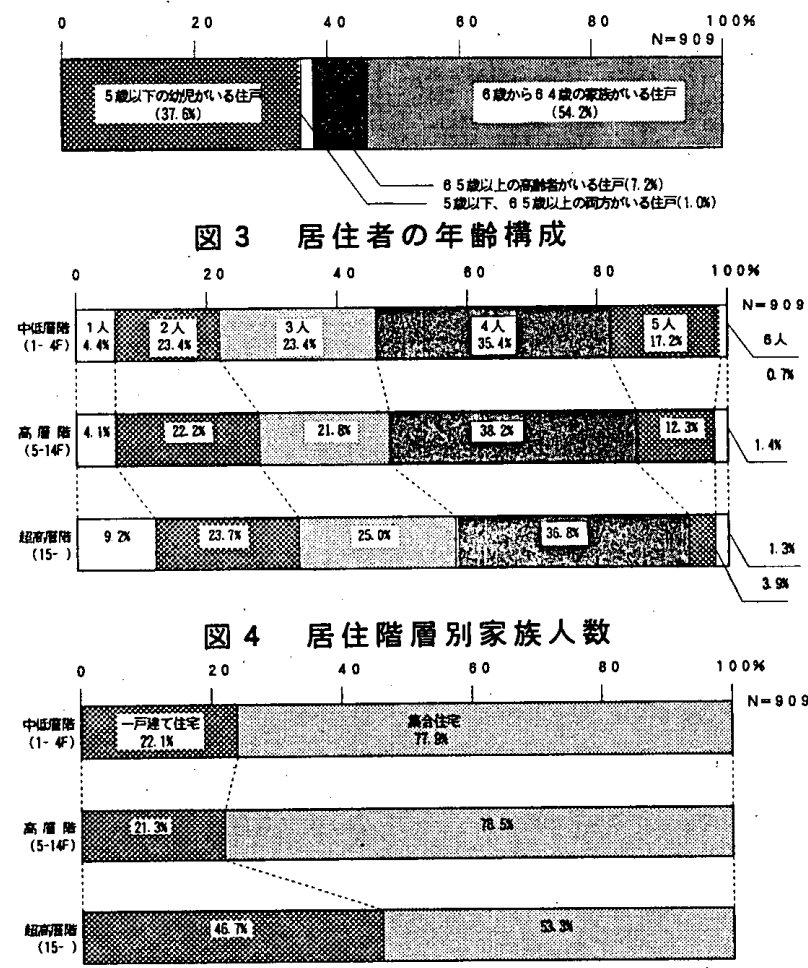

図 5 現在の住居に転居する以前の住戸

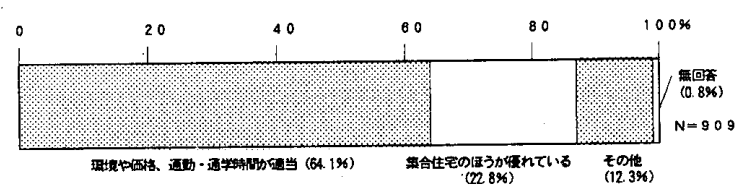

図6 現在の集合住宅を購入した理由
住戸の割合がどの居住階層でも約 $70 \%$ と多く、居住階 層による違いは見られない。過半数の住戸が現在の居 住階に満足していると考えられる。現在の居住階より 高い階を希望する住戸の割合は、超高層階層では $22 \%$ であるが、中低層階層になると $29 \%$ に增加する。低層 階に居住する住戸ほど現在より高層階での居住を希望 する傾向がある。また、現在の居住階より低い階を希 望する住戸の割合は、中低層階では $2 \%$ と少ないが、 この理由のーつとして 1 階の住戸はより低い階を選択 できないことがあげられる。しかし、超高層階層では 現在の居住階より低い階を希望する住戸の割合が約 12 \%であり、高層階になるほど現状の居住階より低い階 を希望する傾向がある。図11k現在の居住階より高い 階を希望する理由を示す。「眺望の良さ」(№.3)が59\% と最も多く、「自動車等の騒音からの解放」(№.5)が 1

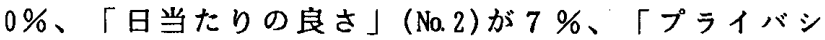
一が確保される」(№.7)が $6 \%$ あるる。図12に現在の居 住階より低い階を希望する理由を示す。「外出の利便 さ」(No.1)をあげる住戸が $33 \%$ と最も多く、「悹と同じ 高さに緑が見える」(№.6)が20\%、「地震・火災時の避 難が有利」(№.2)が19\%である。

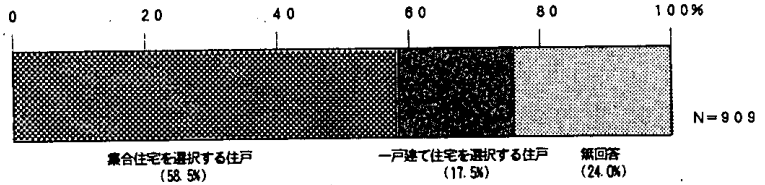

図 7 集合・—戸建て住宅を選択する住戸の割合

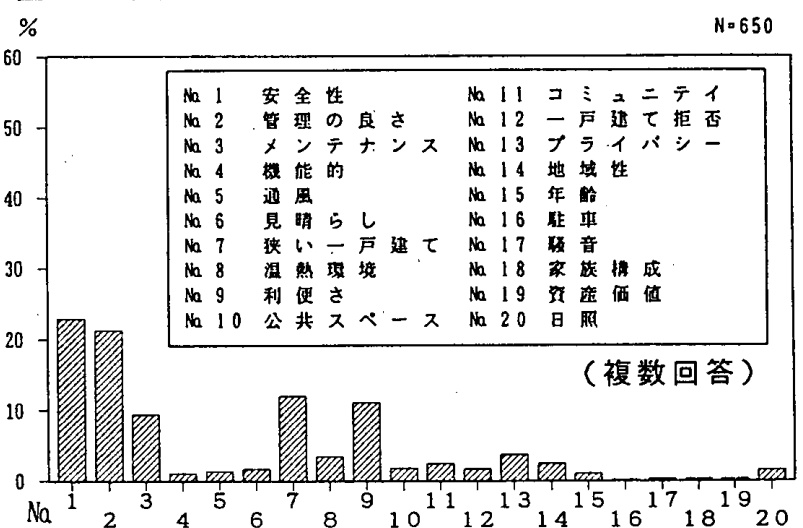

図 8 菓合住宅を選択する理由

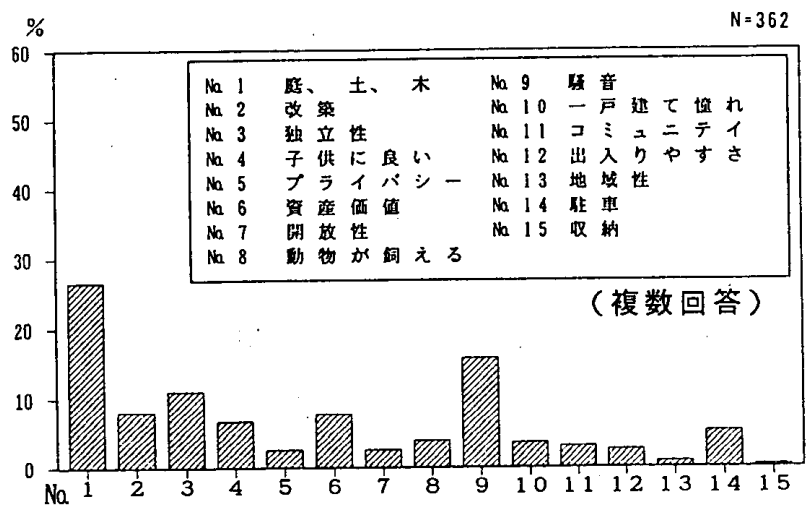

図9一戸建て住宅を選択する理由 


\section{5 主婦の外出の頻度}

図13に主婦の 1 日の居住階層別外出頻度を示す。1 日に 3 回以上外出する主婦の割合はどの階層です $21 \%$ 前後であり居住階層による大きな差はない。1日に2 回外出する主婦の割合は、中低層階・高層階では $39 \%$ $37 \%$ あるが、超高層階では $31 \%$ と減少する。1 日に 1 回しか外出しない主婦の割合は、中低層階、高層階 でそれぞれ31\%、32\%であるが、超高層階は $41 \%$ と增 加している。また、1日に全く外出しない主婦の割合 は、中低層階で $0.9 \%$ 、高層階で $1.6 \%$ 、超高首階では $2.7 \%$ となり、高層になる程外出しない主婦の割合が 增加する。

\section{6 子供の遊ひ場の範囲}

図14に子供の遊び場の範囲を居住階首別に示す。団 地内の公園で遊ぶ割合が各階首とす70 80\%と多く、 居住階層による差は殆どない。共用廊下で遊ぶ割合は、 中低層階が $3.6 \%$ 、高首階では $3 \%$ 、超高首階では全く 見られなくなる。室内で遊ぶ割合は、各階首とも約 12 \%で居住階首による差は見られない。

\section{5 クロス集計結果}

居住者の年齢層と居住階層が、居住者の住まい方や 設備に対する意識にどのような影響を与えているかを 解析するため、居住者の年踰層別居住階層別のクロス
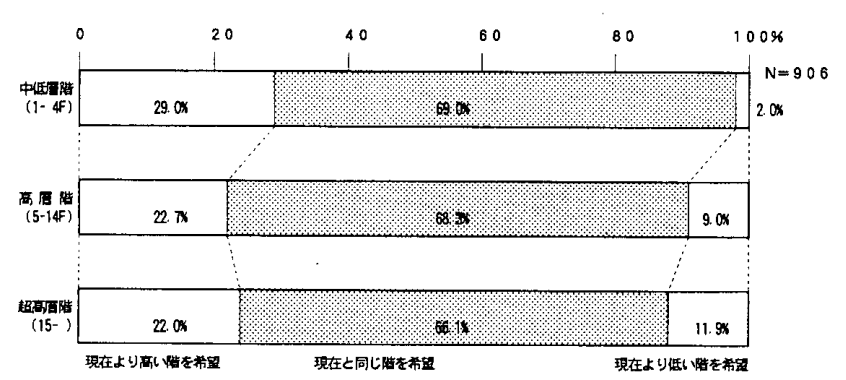

図 10 低層・高層居住を希望する住戸の割合

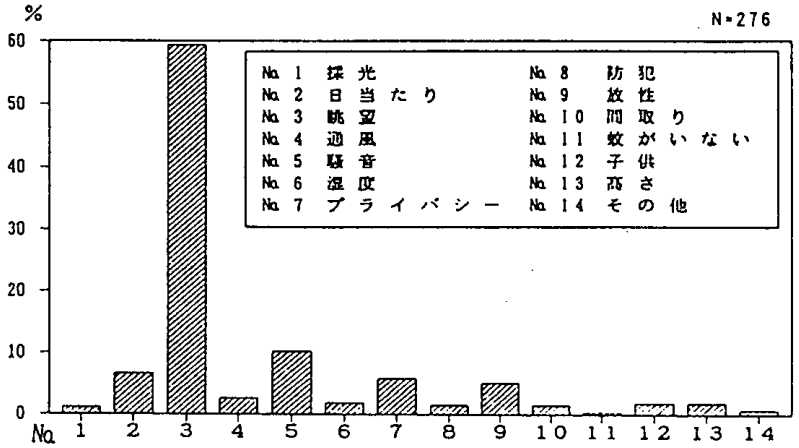

図11高層居住を選択する理由

表 5 住棟別「共用廊下が不安」

と回答した住戸数と割合

\begin{tabular}{|c|c|c|c|c|c|c|c|c|c|c|}
\hline 模 & A & B & c & D & E & $F$ & G & 1 & J & 合 $\mathrm{b}$ \\
\hline 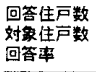 & $\begin{array}{r}13 \\
128 \\
10.18\end{array}$ & $\begin{array}{r}99 \\
94 \\
9.6 \mathrm{~K}\end{array}$ & $\begin{array}{r}2 \\
36 \\
5.6 x\end{array}$ & $\begin{array}{r}18 \\
89 \\
20.2 x\end{array}$ & $\begin{array}{r}22 \\
143 \\
15.4 \times\end{array}$ & $\begin{array}{r}15 \\
117 \\
12.8 x\end{array}$ & $\begin{array}{r}27 \\
124 \\
21.8 x\end{array}$ & $\begin{array}{r}16 \\
165 \\
10.8 x\end{array}$ & $\begin{array}{r}4 \\
53 \\
7.5 x\end{array}$ & $\begin{array}{r}126 \\
999 \\
13.95\end{array}$ \\
\hline 住搷形望 & $\begin{array}{l}\text { 分敬 } \\
ב 7\end{array}$ & $\begin{array}{l}\text { 分散 } \\
\text { コア }\end{array}$ & $\begin{array}{l}\text { 分散 } \\
\text { כד }\end{array}$ & $\begin{array}{l}\text { センタ } \\
\text { ーコ7 }\end{array}$ & $\begin{array}{l}\text { 分敞 } \\
د 7\end{array}$ & $\begin{array}{l}\text { 分敝 } \\
\text { בร }\end{array}$ & $\begin{array}{l}\text { センタ } \\
-\unlhd 7\end{array}$ & $\begin{array}{l}\text { 分敬 } \\
\text { J }\end{array}$ & $\begin{array}{l}\text { 分触 } \\
\text { ב }\end{array}$ & \\
\hline
\end{tabular}

集計を行う。居住者の年齢首は、 $0 \sim 2$ 葴、 $3 \sim 5$ 歳、 $6 \sim 11$ 歳、12〜17歳、18〜 64葴、65歳以上に分類し、 それぞれの年龄層の居住者がいる住戸を集計対象住戸 とする。表 6 に、居住階首別・年齢屏別の人数及びク 口ス集計の線種を示す。

\section{1 住棟 内で不安を感じる場所}

「住棟内で不安を感じる場所」に関するクロス集計 結果を図15に示す。中低層階と高層階の居住者では、 どの年齢層のいる住戸も「エレベーターの中」が最も 不安と感じており、よく似た傾向を示す。一方、超高 首階は、「共用廊下」と「エレベーターの中」の 2 䇢 所にピークがある。これは、センターコア型の住棟形 態に起因すると考えられる。また、年齢首別にみると、 中低層階では65歳以上の高齢者のいる住戸で「エレべ 一ターの中」が $62 \%$ と最高い。高層階では、どの年 齢層です「エレベーターの中」が最す多く $50 \%$ 前後で あり、年齢層別に大きな違いは見られない。超高層階 では、 $0 \sim 2$ 歳の乳児がいる住戸が「エレベーターの 中」が $82 \%$ と極めて高い。 $3 \sim 5$ 歳の幼児がいる住戸 では、「1階玄関」が $38 \%$ と最も多く、「エレベータ 一の中」は $36 \%$ ある。また、6〜11歳の児童がいる 住戸、12〜17歳の学生がいる住戸、18〜 64歳の成人が

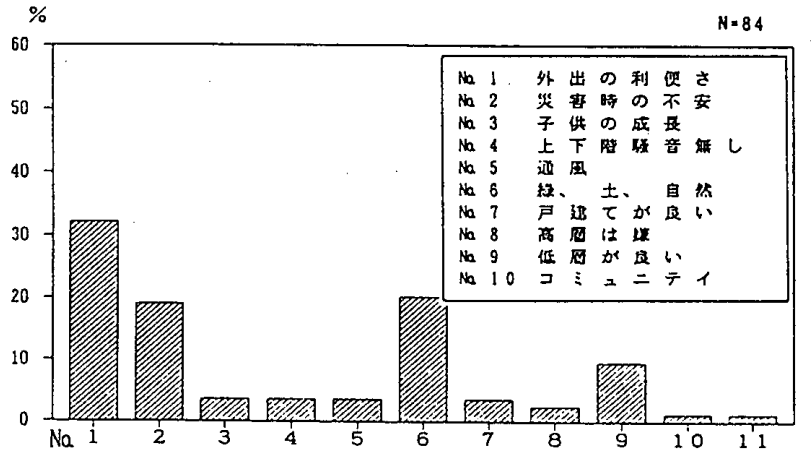

図12低層居住を選択する理由

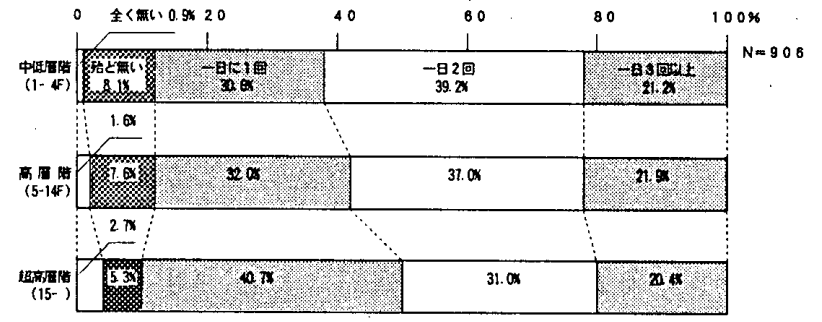

図13主婦の外出の頻度

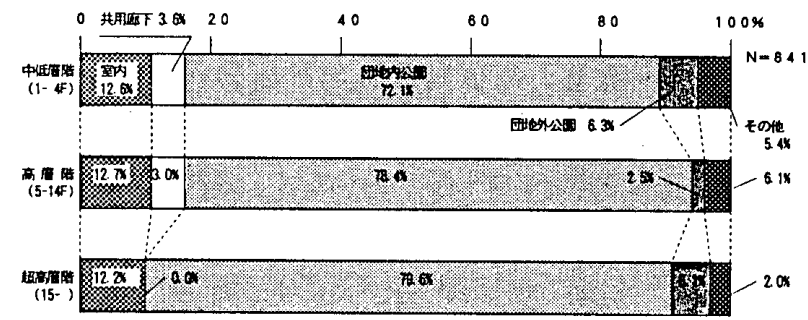

図14子供の遊び場の範囲 
いる住戸では、「共用廊下」が50\%前後と最も多く 「エレベーターの中」は $30 \%$ 前後でありよく似た傾向 を示す。65歳以上の高踰者がいる住戸は、「エレベー ターの中」が $47 \%$ と最も多い。また、表 5 に「共用廊 下が不安」と回答した住戸数とその割合を住棟別に示 す。センターコア型の住棟形態である D 棟が $20.2 \%$ 、 $\mathrm{G}$ 棟が $21.8 \%$ と特に高く、分散コア型である他の住棟 は $10 \%$ 前後であり、共用廊下が不安と感じるのは住棟 形態に起因していると考えられる。

\section{2 エレベーターに対する意識}

「どのようなエレベータが安心だと思われますか」 という設問の回答結果を図16に示す。（以降エレべー タは E Vと記す。）どの居住階層です、「防犯カメラ 付きでセンタ一監視している E V」の割合が最む高く、 次いで「窓のあるドアが付いた E V」の割合が高い。 また、年齢層によるばらつきは高層階が最す少なく、 次いで中低層階の順となり、超高層階のばらつきが最

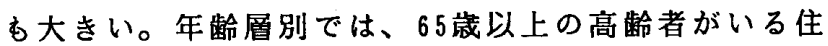
戸で、「防犯カメラでセンター監視している E V」の 割合が中低層階 $48 \%$ 、高層階 $61 \%$ 、超高首階 $71 \%$ と高 層階になるほど高く、他の年路層より大きい值を示す。 5.3 主婦の外出頻度

主婦の外出頻度に関する集計結果を図17に示す。0 〜 11歳の子供がいる住戸の主婦が一日に 2 回外出する 割合は、どの居住階層でも約 $40 \%$ であり、3 回以上外 出する割合でも、中低層階において0〜2歳の子供が いる住戸の主婦の割合が $16 \%$ であが、全体では約 40 \%前後である。これより、0〜11歳の子供がいる住戸 の主婦が一日に2 回以上外出する割合は、居住階層に よる違いはあまり見られず約 $80 \%$ と高い。一方、65歳 以上の高歯者がいる住戸の主婦の外出頻度は、高層階 になるほど減少する傾向があり、超高層階層では一日 に 3 回以上外出する主婦の割合は $0 \%$ ある。

\section{4 子供の遊ひ場の範囲}

子供の遊び場の範囲に関する集計結果を図18に示す。 子供の遊び場の範囲は、「 $0 \sim 2$ 歳の乳児がいる住戸」 「 $3 \sim 5$ 歳の幼児がいる住戸」、「6〜11歳の児童が いる住戸」では、どの居住階層においても「団地内の 公園で遊ぶ」割合が最も多く、各年澮層による差は殆 ど無い。また、超高層階層では「団地内の公園で遊ぶ」 割合が最も高いが、一方、子供の年齢層が高くなるほ

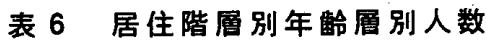

\begin{tabular}{|c|c|c|c|c|c|}
\hline 楾稙 & 年龄瘁 & 中低㕆 & 蛊展 & 怊离同 & 合尌 \\
\hline - & $0 \sim 2$ 栈 & 42 & 84 & 29 & 155 \\
\hline - & $3 \sim 5$ 煘 & 43 & 127 & 24 & 194 \\
\hline$=$ & $6 \sim 11$ 㖪 & 84 & 152 & 22 & 258 \\
\hline . & $12 \sim 17$ 瓷 & 43 & 82 & 16 & 141 \\
\hline (n........... & $18 \sim 64$ 极 & 290 & 491 & 107 & 888 \\
\hline $\bar{\cdots}$ & 65諴以上 & 16 & 36 & 15 & 67 \\
\hline
\end{tabular}

楾種と年夦層は、図15〜18の線璉に対応している。

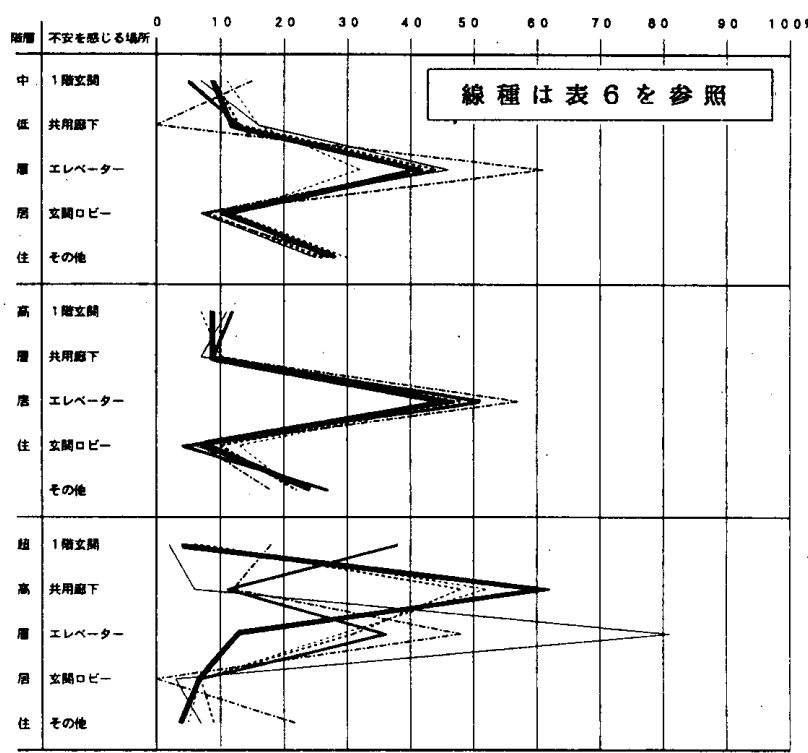

図15住棟内で不安を感じる場所

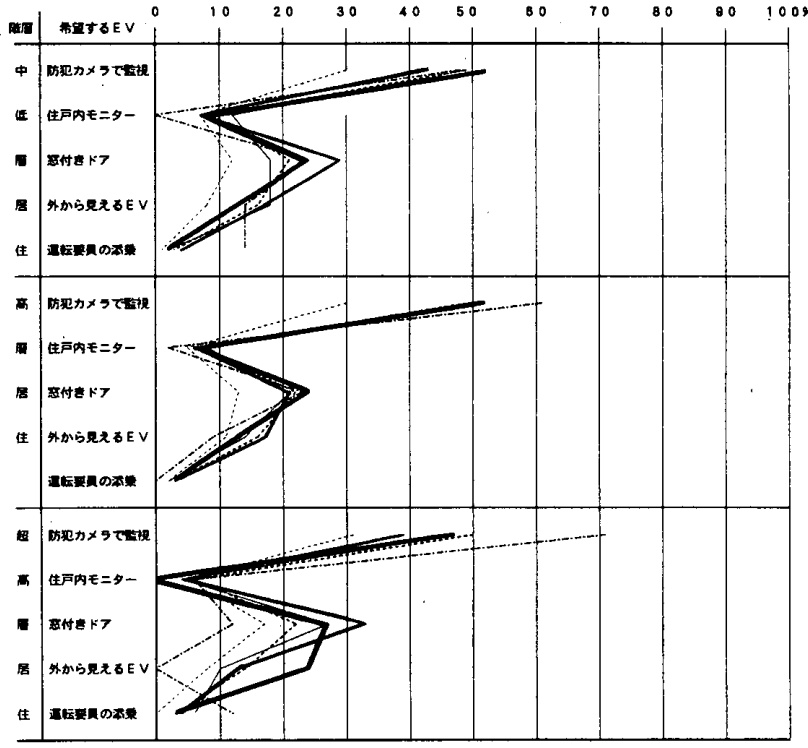

図16 希望するエレベーター

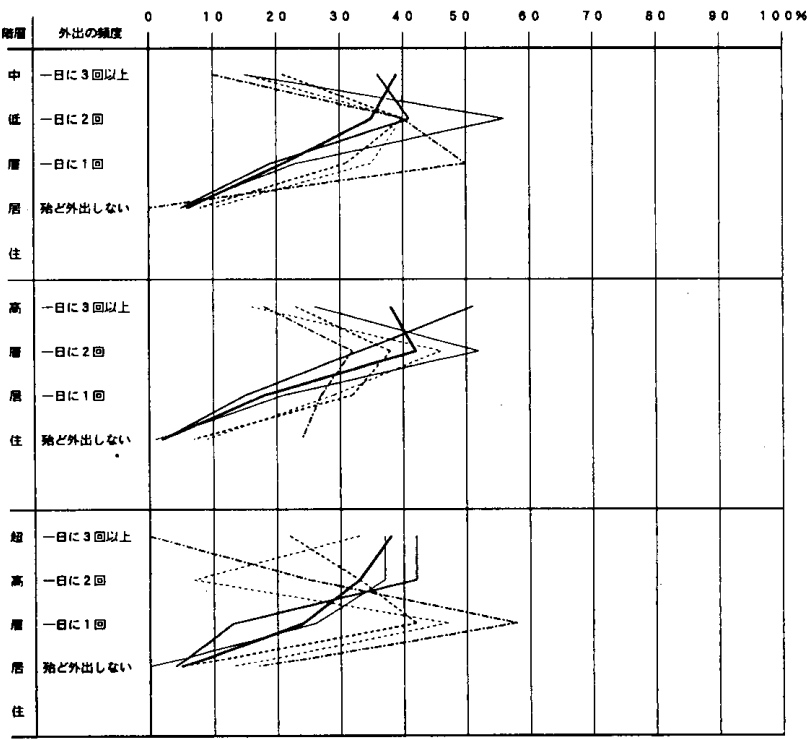

図17主婦の外出頻度 
ど「部屋の中で遊ぶ」割合が增加している。これは、 子供の自立が確立してくる年踰層である小学生や中学 生では、戸外での遊びから T V ゲーム等室内での遊び に変化することに起因しているためと考えられる。

\section{6 数量化理論 ॥類を用いた分析}

前章までに、居住者の年踰層別、居住階層別に居住 意識や住まい方に関する集計を行い、実態を把握した。

本章では、居住者の居住意識や住まい方にどの様な 要因が影響を与えているのかを把握するため、数量化 理論 II 類を用いた分析を行う。目的変数は、居住者の 居住意識に関しては希望住戸形態と希望居住階層を取 り上げ、住まい方に関しては子供の遊び場の範囲と主 婦の外出頻度を取り上げる。分析に使用する説明変数 は、アンケート調查内容に基づき、目的変数に影響を 与えていると考えられる全ての要因を選択しステップ ワイズ法により最適変数を決定する。表 7 に数量化理 論 II 類でステップワイズ法変数選択に用いた因子を示 す。要因 1 の棟高から要因 6 の平均年踰までは定量デ 一タであり、要因 7 の職業から要因19の防犯カメラま では定性データである。

6.1 希望住戸形態に関する分析結果

「現在のお住まいと同じ立地条件の一戸建て住宅 (床面積は現在と同様で庭の面積はバルコニーの面積 の 2 倍程度）が同じ価格で販売されていたら集合住宅 と一戸建て住宅のどちらを選択しますか」という設問 に対する回答に関して、集合住宅を選択する住戸を 1 に、一戸建て住宅を選択する住戸を 0 に分類し、これ を外的基準として数量化理論 II 類による分析を行った。 表 8 に分析結果を、図19に判別グラフを示す。分析対 象住戸数は、無回答 1 住戸を除く908住戸である。ステ ップワイズ法の結果、判別式に投入された変数は14で あり、判別的中率は、61.5\%である。集合住宅を希望す る群に寄与するカテゴリーは、「現在の居住階と同じ 高さかもっと高い階に住みたい」、「集合住宅の安全 性、管理の良さにひかれている」である。集合住宅を 希望する主な要因は、4.3節の单純集計結果に見られる ように集合住宅の管理の良さや利便性と高層居住を希 望する意識と考えられる。また、一戸建て住宅を希望 する群に寄与するカテゴリーは、「 3 荗以上 5 嵅以下 の幼児がいる住戸や12歳以上 17 歳以下の学生がいる住 戸」、「通勤・通学・価格で現在の住戸を選択した」、 「オートロックの使い勝手には問題がある」、「オー トロックはまったく役にたっていない」である。一戸 建て住宅を選択する要因は、子供のいる家族構成と防 犯設備に対する不信、現在の集合住宅を購入した理由 の背景にある一戸建て住宅に対する意識と推察される。 このことは、一戸建て住宅を選択する理由（図9）に
示すように庭、土、木といった自然との接触や上下階 の騒音からの解放という理由が最す多い結果からも伺 える。

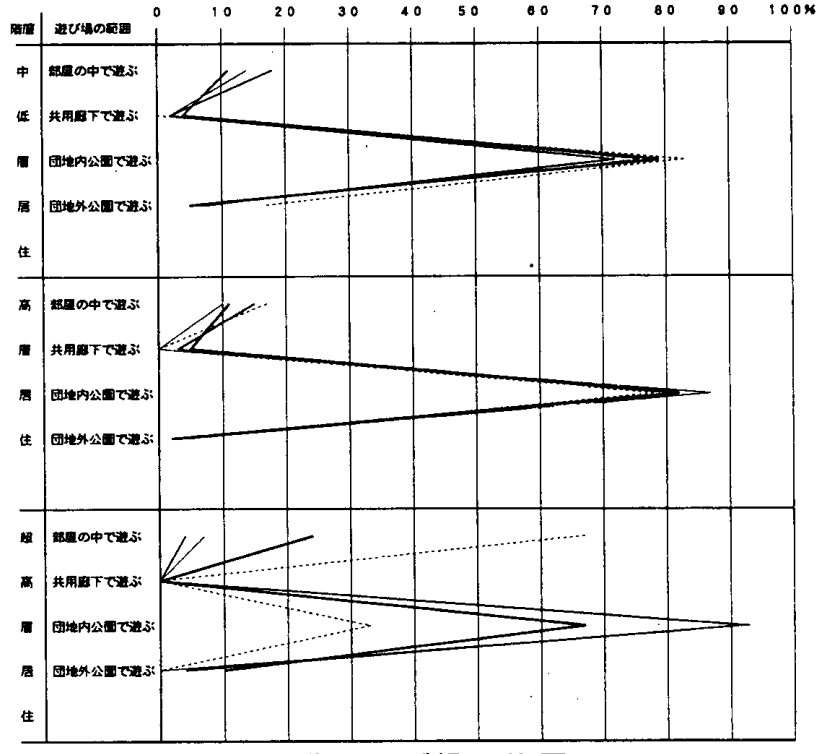

図18 子供の遊び場の範囲

表 7 ステップワイズ变数選択に用いた因子

\begin{tabular}{|c|c|c|c|}
\hline \multicolumn{2}{|c|}{ 要 因 } & \multirow{2}{*}{$\begin{array}{c}\text { カ テ ゴ リー } \\
\text { 居住している体棟の畐さ }\end{array}$} & \multirow{2}{*}{ 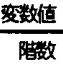 } \\
\hline 1 & 楝高 & & \\
\hline 2 & 居住階 & 居仿している陆 & 院数 \\
\hline 3 & 床面樌 & 属住している佳戸の林面樌 & $\overline{m^{2}}$ \\
\hline 4 & 家族の年数搆成 & 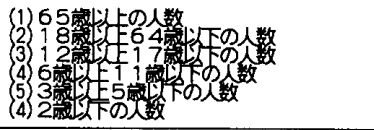 & 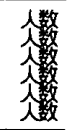 \\
\hline 5 & 家族人数 & 同居している家族の人数 & 人数 \\
\hline 6 & 平均年跲 & 同居している家族の平均年蛒 & 峝 \\
\hline 7 & 瞳 賟 & 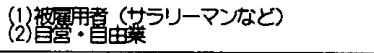 & b \\
\hline 8 & 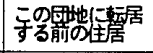 & 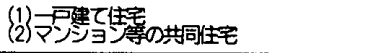 & $\begin{array}{l}1 \\
0\end{array}$ \\
\hline 9 & 沃集荛倩宅に & 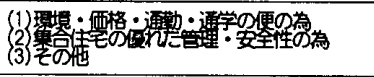 & $\begin{array}{l}1 \text { oro } \\
1 \text { oro } \\
1 \text { oro }\end{array}$ \\
\hline 10 & 希望住戸形㿟 & 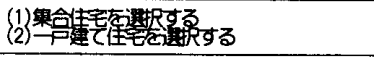 & $\begin{array}{l}1 \\
0\end{array}$ \\
\hline 11 & 居住希望喈 & 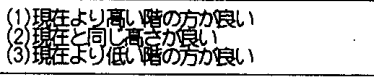 & $\begin{array}{l}1 \\
2 \\
3\end{array}$ \\
\hline 12 & 主婂の仕事 & 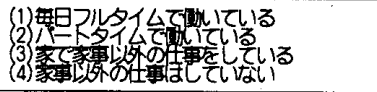 & $\begin{array}{l}\text { 1 oro } \\
\text { foro } \\
\text { foro } \\
\text { 1oro }\end{array}$ \\
\hline 13 & 子供の遊び婸 & 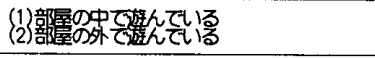 & $\begin{array}{l}1 \\
0\end{array}$ \\
\hline 14 & $\begin{array}{c}\text { 主婦の外出頻度 } \\
\text { (平员) }\end{array}$ & 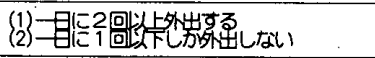 & $\begin{array}{l}1 \\
0\end{array}$ \\
\hline 15 & 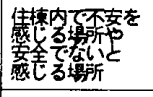 & 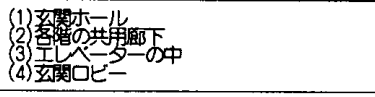 & $\begin{array}{l}1 \text { oro } \\
1 \text { oro } \\
1 \text { oro } \\
1 \text { oro } \\
\end{array}$ \\
\hline 16 & 茎全と感じる & 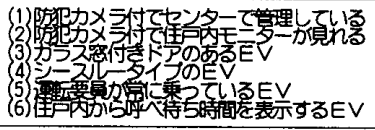 & $\begin{array}{l}1 \text { oro } \\
1 \text { oro } \\
1 \text { oro } \\
1 \text { oro } \\
1 \text { oro } \\
1 \text { oro }\end{array}$ \\
\hline 17 & 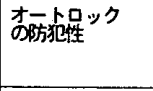 & 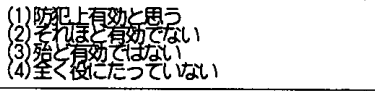 & $\begin{array}{l}1 \text { oro } \\
1 \text { oro } \\
1 \text { oro } \\
1 \text { oro }\end{array}$ \\
\hline 18 & 势操偘ック & 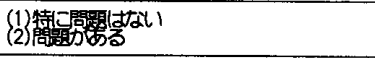 & $\frac{1}{0}$ \\
\hline 19 & 防犯がラ & 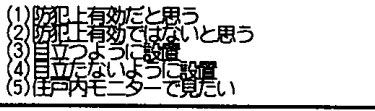 & $\begin{array}{l}1 \text { oro } \\
1 \text { oro } \\
\text { 1 oro } \\
\text { 1 oro } \\
\text { ioro } \\
\end{array}$ \\
\hline
\end{tabular}

（注）回答があった㧹合を1、回答か無かった軥合を0とする。 


\section{2 希望居住階層に関する分析結果}

「もし集合住宅に引っ越しするとすれば何階に引っ 越したいと思いますか」という設問に対する回答に基 づき、現在の居住階より高い階を希望する住戸を 1 に、 現在の居住階と同じ階を希望する住戸を 2 に、現在の 居住階より低い階を希望する住戸を 3 に分類し、これ を外的基準として分析を行った。表 9 に分析結果を、 判別グラフを図20に示す。分析対象住戸数は、無回答 1 住戸を除く908住戸である。判別式に投入された変数 は17であり、判別的中率は66.5\%である。現在の居住階 を希望する群に寄与するカテコリーは、「一戸建て住 宅を希望する」、「2 歳以下の幼児がいる住戸」、 「住棟内で、 $\mathrm{EV}$ 内部に不安を感じる」、「防犯力メ ラは、防犯上有効ではない」等である。また、現在の 居住階より高い階を希望する群に奇与するカテコリー は、「世帯主の職業は自営・自由業」、「主婦は每日 フルタイムで働いている」、「集合住宅の安全性、管 理の良さにひかれた」等である。現在の居住階より低 い階を希望する要因は、一戸建て住宅を希望する意識 と自然とのふれあい（図 12参照）と子供のいる家族構 成、住棟内の不安な場所と防犯設備に対する不信であ る。また、現在の居住階より高い階を希望する要因は、 世帯主の職業と主婦の就業状況、集合住宅の持ってい る外出の利便さ（図11参照）である。なお、現在の居 住階より低い階を希望するカテゴリーの中で「現在居 住している階数」のウェイトが最も高い。これは、1 階に居住する住戸は現在より低い階は選択できず選択

表 8 希望住戸形態に関する分析結果

\begin{tabular}{|c|c|c|}
\hline & テ ゴリ - & ウェイト \\
\hline 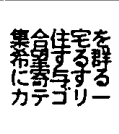 & 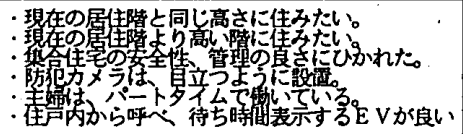 & $\begin{array}{l}71.9 \\
56.4 \\
56.2 \\
21.3 \\
12.0 \\
11.3\end{array}$ \\
\hline 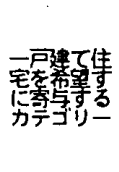 & 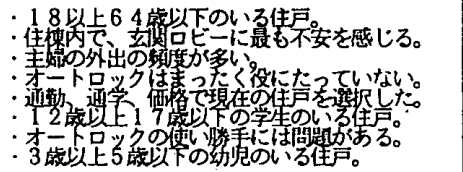 & $\begin{array}{l}-13.1 \\
-16.1 \\
-16.2 \\
-18.4 \\
-20.4 \\
-21.2 \\
-23.5 \\
-23.6\end{array}$ \\
\hline
\end{tabular}

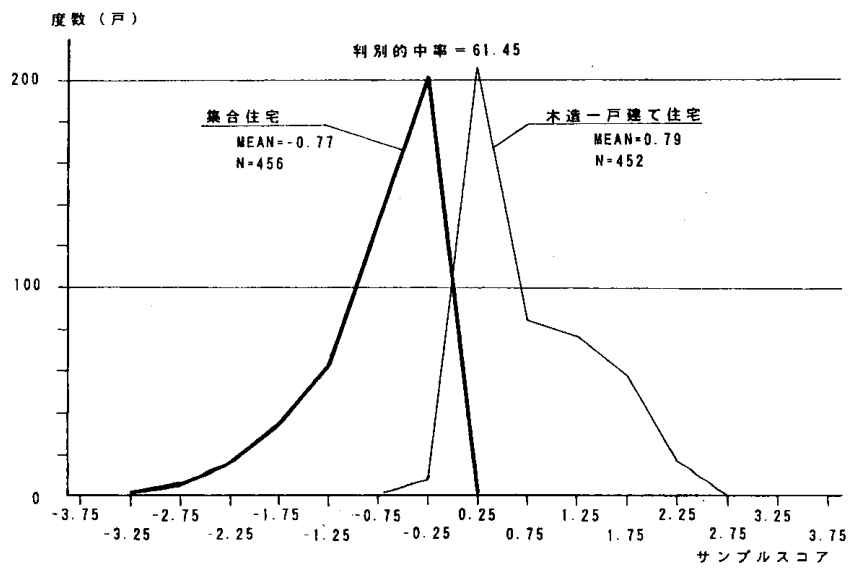

図19希望住戸形態判別グラフ
の自由度が少ないためであり、このカテコリーを要因 と判断することは不適当と考えられる。

\section{3 子供の遊び場に関する分析結果}

子供の遊び場の範囲について、「部屋の中で遊ぶ」 と回答した住戸を 1 に、「部屋の外で遊ふ」と回答し た住戸を 0 に分類し、これを外的基準として分析を行 った。表10に分析結果を、図21に判別グラフを示す。 分析対象住戸数は、17歳以下の子供のいる住戸841住 戸である。判別式に投入された変数は19であり、判別 的中率は $88.8 \%$ である。部屋の外で遊ぶ群に寄与する カテコリーは「 0 歳以上 2 歳以下の乳児がいる住戸」、 $\lceil 3$ 歳以上 5 歳以下の幼児がいる住戸」、「6 歳以上 11 歳以下の児童がいる住戸」、「主婦は家事以外の仕 事はしていない」、「主婦の外出頻度は高い」等であ る。部屋の中で遊ぶ群に奇与するカテコリーは、「同 居している家族の平均年齢」、「同居している家族の 人数」、「住棟内では共用廊下が最も不安である」、 「主婦はパートタイムで働いている」等である。 0 歳 から11歳までの子供は外で遊ぶ群に判別されやすく、 12歳以上になると部屋の中で遊ぶ群に判別されやすい。 また、主婦が㗢きに出ず家の中にいる住戸の子供ほど 部屋の外で遊ぶ群に判別される傾向がある。また、住 棟内で最も不安な場所と指摘される「共用廊下」は、 子供の遊び場を室内に限定する一要因と考えられる。

表 9 希望居住階層に関する分析結果
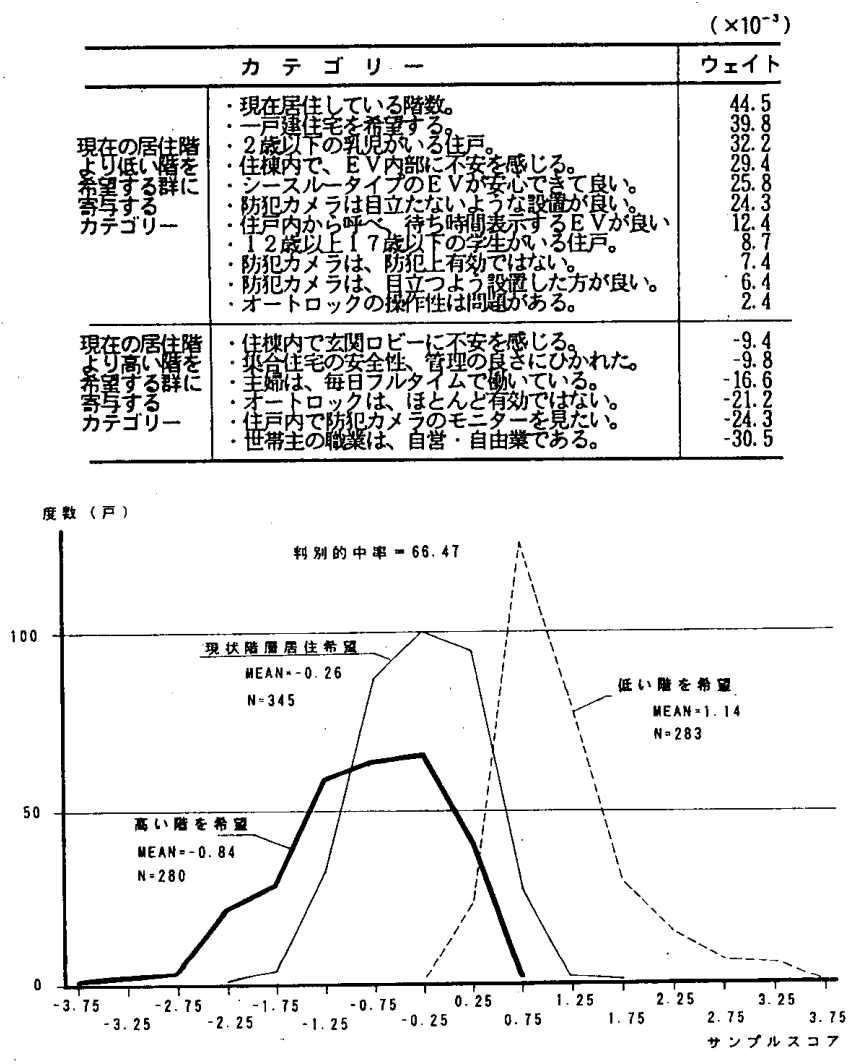

図 20 希望居住階層判別グラフ 


\section{4 主穆の外出頻度に関する分析結果}

主婦の外出頻度に関して、一日 1 回以下と回答した 住戸を 0 に、一日 2 回以上と回答した住戸を 1 に分類 し、これを外的基準として分析を行った。表 11 に分析 結果を、図22に判別グラフを示す。分析対象住戸は、 無回答の住戸 3 住戸を除く906住戸である。判別式に投

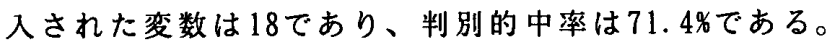
外出頻度が高い群に寄与するカテゴリーは、「子供は 部屋の外で遊ぶ」、「主婦は家事以外の仕事はしてい ない」、「主螮はパートタイムで仕事をしている」、

$\lceil 3$ 歳以上 5 歳以下の幼児がいる住戸」等である。外 出頻度が低い群に判別されるカテコリ一は、「主婦は 毎日フルタイムで働いている」、「同居している家族 の平均年粭」である。外出頻度が高くなるのは、比較 的家にいる時間が長い主婦であり、子供の付き添いや 買い物などで外出する頻度が高くなるものと推察され る。フルタイムで働く主婦は朝出勤すると夕方まで帰 宅しない為、外出頻度が低くなると考えられる。また、 平均年齢が高くなると外出頻度が低くなるのは、高齢 者になるほど外出頻度が低くなるためと考えられる。

\section{7 まとめ}

(1)現在の住宅と同じ立地条件の一戸建て住宅（床面 積は現在と同様で庭の面積はバルコニーの 2 倍程度） が同じ価格で販売されていた場合、一戸建て住宅より 集合住宅を選択する住戸のほうが多い。その理由とし て、集合住宅の持つ「安全性や管理・メンテナンスの 良さ」、「鍵一つで外出できる利便さ」、「高層居住 を望む」等があげられる。一方、一戸建て住宅を選択 する住戸は、「自然との共生」、「子供の教育上の問 題」、「上下階の騷音問題からの開放」、「住宅の独 立性」等が大きな要因と推察される。また、図 7 にお いて集合住宅を選択する住戸の割合が約 $59 \%$ にな、 従来の一戸建て住宅偏重の傾向に反する結果を示して いる。調查対象団地の居住者の年秢構成（図3）では、 保育を終えた 6 歳から64歳の居住者がいる住戸の割合 が約 $54 \%$ を占め、居住開始から 1 年〜 7 年経過してい ることを考虑すると、この結果は東樋口らの研究（表 1、№.16）において、「住替え希望住宅が居住者のラ イフステージの伸長、言い替えれば、居住者の年跉首 が高くなるほど集合住宅居住希望が増加する。」とい う結論を裹付けており、集合住宅居住者は住み替え希 望として積極的に集合住宅を選択するものと考えられ る。その理由としては、集合住宅の持つ安全性や管理 の良さ、利便さが上げられる。

(2)居住階に対する希望については、「もしもこれから 集合住宅に引っ越すなら、現在居住している階と同じ 階を希望する」と回答する住戸の割合が最も多く、居

\section{表10 子供の遊び場の範囲に関する分析結果}
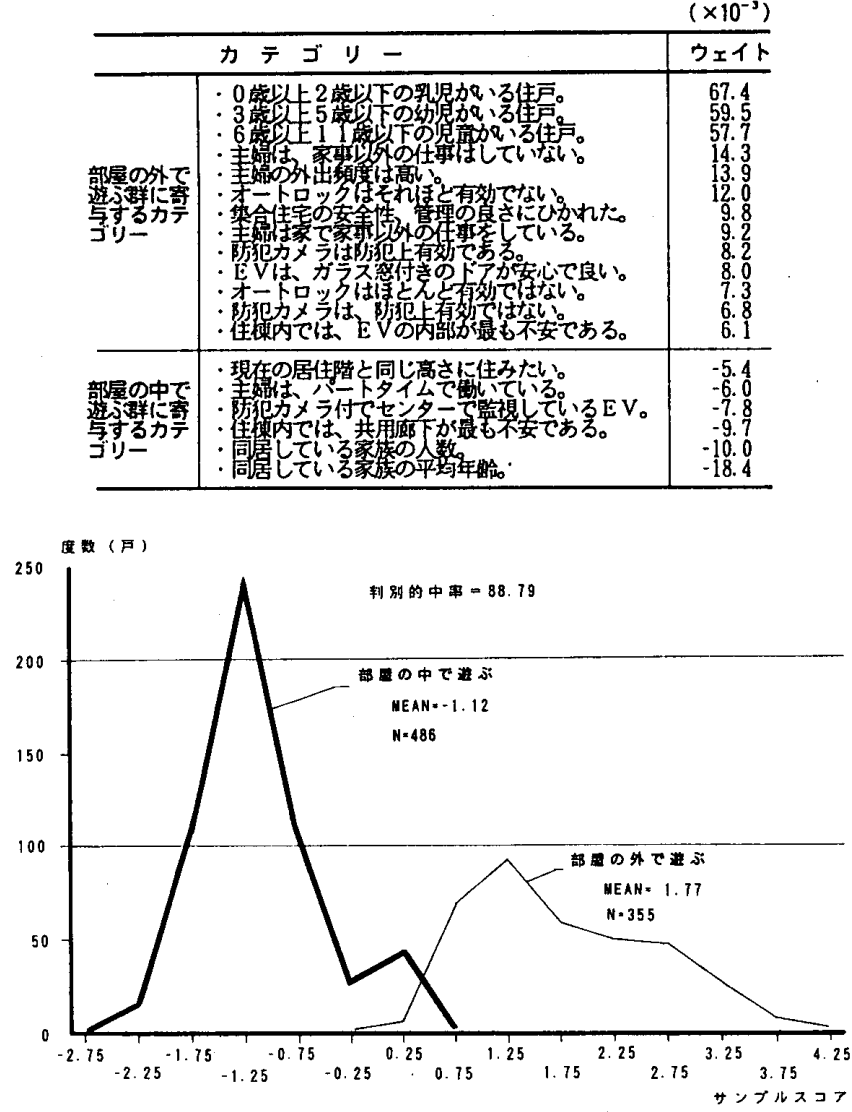

図21子供の遊び場の範囲判別グラフ

表11主婦の外出頻度に関する分析結果
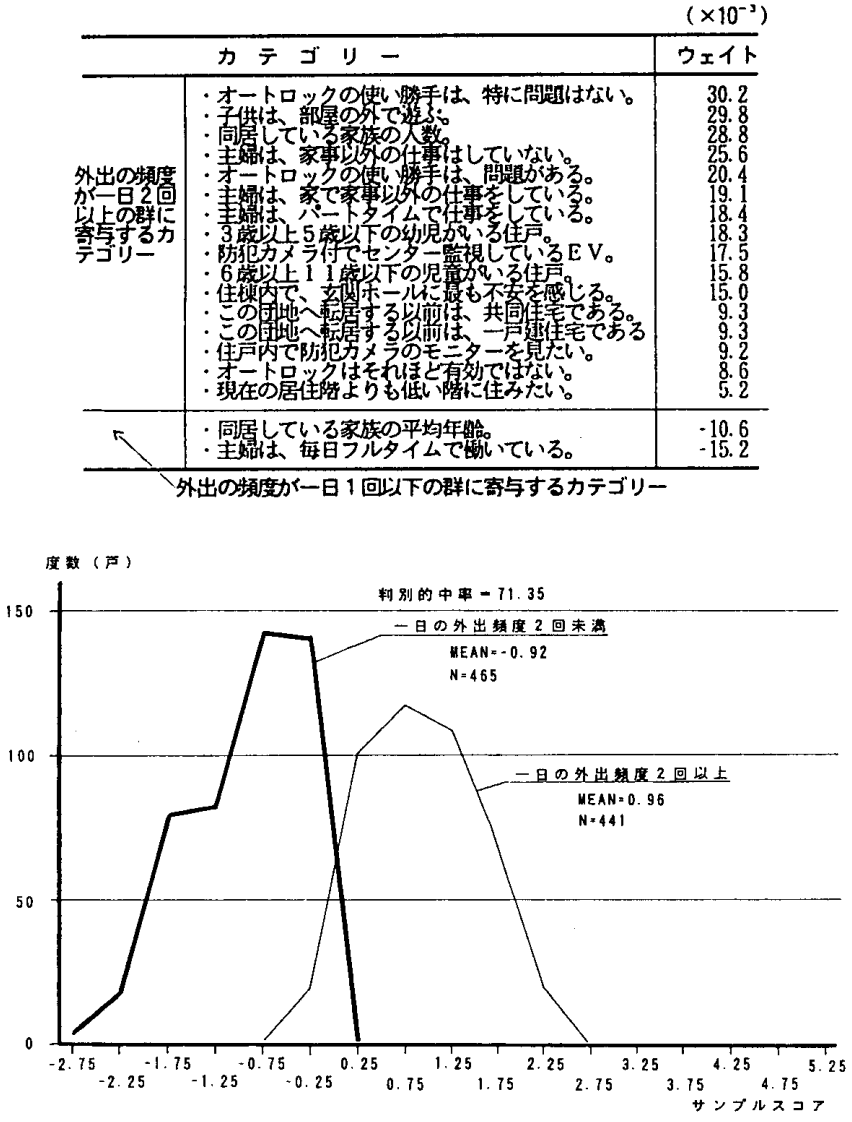

図22主婦の外出頻度判別グラフ 
住階層による違いは見られない。これは、過半数の住 户は現在の居住階に满足しているものと推察される。 また、どの階層に居住する住戸でも現在の居住階より 高層階への居住を希望する割合が $25 \%$ 程度である。但 し、高層階になるほど現在の居住階より低い階を希望 する傾向もみられ、その理由は、外出の利便さ、自然 とのふれあい、災害時の避難に有利なためである。

(3)住棟内の不安な場所については、居住階層と年齢 層による差が見られる。特にエレベータ一の中で不安 を感じる割合が最も高く、さらに超高層階になると共 用廊下の割合も高くなる。住棟内では利用せざるを得 ないエレベーターは、 $0 \sim 2$ 歳の乳児や65歳以上の高 歯者がいる住戸で特に「不安な場所」と感じる割合が 高く、更に、高層になる程增加し超高層階では $80 \%$ に なる。これは、高層になるほど乗っている時間が長く 密室状態が続き犯罪発生の恐怖を感じるためと推察さ れる。エレベーターの開放性・防犯性・監視性の改善 が望まれており、これは希望するエレベータ一の回答 結果からも伺える。更に、住棟内で不安を感じる場所 に指摘された共用廊下は遊び場としての評価は低いと 考えられる。特に、超高層住棟の共用廊下は不安を感 じる割合が高く、遊ばせない傾向が見られる。これは センターコア型の住棟形態に起因するところが大きく、 小柳津らの研究（注 8) で、今回対象とした住棟の共 用廊下について「暗く閉しこめられた雾囲気で立ち話 も出来ない」との報告があり、日常的な通路空間とし ては問題があると考えられる。

(4)子供の遊び場の範囲は、年齢層による差異が認め られる。 $0 \sim 2$ 歳の乳児と $3 \sim 5$ 歳の幼児がいる住戸 では、殆どが団地内の公園で遊ぶ割合が高く居住階層 による違いは見られない。これは、0〜 5 歳という年 龄層では一人で外出することができず、母親が付き添 って公園に連れ出すため（注 9 ）と考えられる。また、 6 歳以上から室内で遊ぶ傾向が現れ始め高層階になる ほどその割合が高い。これは、この年秢層から外出に 対する自立が確立し、高層階になるほど外出が煩わし くなること、遊びの質的変化 ( $\mathrm{T} V$ ゲーム等の室内要 素が加わること）等によるものと考えられる。

（5）5歳以下の子供がいる住戸の主婦の外出頻度は、 子供の付き添いによる外出が多いため、居住階首によ る差は殆ど無い。また、主婦の就業状況別の外出頻度 は、フルタイムで働いているほど低く、家にいる時間 が長いほど高い結果となる。これは、働いている主婦 は朝外出すると夕方まで㷌宅しないしないためと考え られる。一方、65歳以上の高齢者がいる住戸では、中 低層、高層に居住する主婦よりも超高層に居住する主 婦の外出頻度が減少する傾向があり、他の年齢層と比 較しても外出の頻度が相対的に低い。以上の結果から、
主婦の外出の頻度に影製を与える要因は、居住してい る階数のみならず、外出に付き添いが必要な子供の存 在と主婦の就業状况、同居家族の平均年齢であると考 えられる。

\section{謝辞}

本調査を行うに当たり、対象住宅の居住者各位及び 管理センターの各位には多大なこ協力を睗りました。 また、調査対象住宅の選定及び調査結果の解析には、 東京大学生産技術研究所村上周三教授のこ協力を頂 きました。更に、本研究の一部は、文部省科研費・平 成 2 年度重点領域研究から助成を受けて行っており、 東京医科歯科大学高野健人教授、東京大学医学部 大井玄教授、織田正昭先生から有用な助言を頂きまし た。ここに記して感謝の意を表します。

1)1993年10月9日付け朝日新䦥の不䵢産柽済研究所 発表「平成 5 年 9 月の首都图マンション」に閣する記事 上り引用。

2)1991年度日本建筑学会桭境工学部門(2)+都市計画

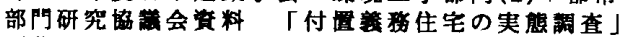
須藤 繪編

3)王世華、尾岛俊飾、三浦昌生：立体用途を考田した 階層別空間利用に関す万実熋調查研究、建築学会新画系 論文郝告集第 410 号、1990年4月

4)本每料は、平成 3 年度重点颃域研究（人間琪境系）

「都市住民における健康諸指㩐のモニタリンクと健康影

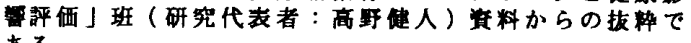
ある。

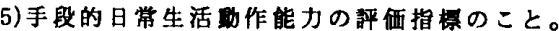

6)中低層、高層、弨高屏階数設定について

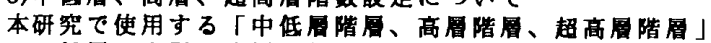
は、低屡、中層、高屏、超高層階として通常道用されて おり、従来の研究でも用いられた階層区分を索に下部表 に示す階数に設定しています。

\begin{tabular}{|c|c|}
\hline 階買 & 階層に相当する階数 \\
\hline 中諙層階層 & $1 \sim 4$ 階 \\
\hline 高層階首 & 5 管 $\sim 14$ 階 \\
\hline 超禀層階層 & 15階以上 \\
\hline
\end{tabular}

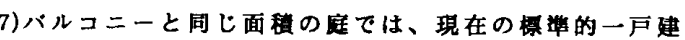
て住宅の来件としては狭すきることや、建坪率なとの法 的规制が满たされず現実的ではないと考えられる。この 点を考盛し、集合住宅と一戸建て住宅との比敕握にお いて怨意性が入らない面稍として、バルコニーの約 2 倍 程度の面皘の庭を設定した。

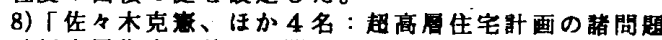
(超高屏住宅の計画に閏する研究‡の 1 )、5092 P183〜P184、1990年10月」より拨した。

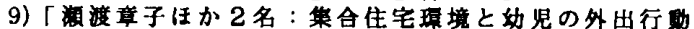
について(その 1 外出行㽖の自立と屋外遊び頼度の住

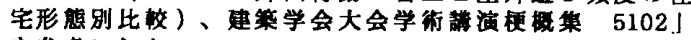
を考にした。

本諭文に関する既発表销文

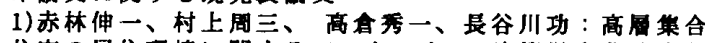
住宅の居住桭境に関するアンケート、建策学会北陸支部 研究告第35号、P227～P230 1992年7月

表 1 に䟕した以外の考文辣

1)高野健人著：「U r b a n H e a l t h

Human-Environmentalinteraction in Megaalopolises and Developing Cities, 数育籍, 1993

2)宫本害一著：「都市をとう生をるか」，小学館 1984

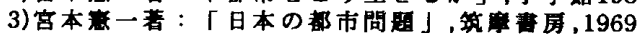

4) SPSS/PC+TK Advansed Statistics V2.0.

エスビーエスエス株式会社

5) Ben T.BOLCH, CLIFF J.HUANG原著，中村訳

「灾用多变量解析」，棵北出版（株） 1979

(1993 年 11 月 10 日原稿受理，1994 年 5 月 30 月採用決定: 